\title{
Zinc transporter gene expression is regulated by pro-inflammatory cytokines: a potential role for zinc transporters in beta-cell apoptosis?
}

\author{
Lærke Egefjord1', Jens Ledet Jensen², Claus Heiner Bang-Berthelsen³, \\ Andreas Brønden Petersen ${ }^{1}$, Kamille Smidt ${ }^{1}$, Ole Schmitz ${ }^{1}$, \\ Allan Ertman Karlsen ${ }^{4}$, Flemming Pociot ${ }^{3}$, Fabrice Chimienti ${ }^{5}$, \\ Jørgen Rungby ${ }^{1}$ and Nils E Magnusson*1
}

Address: ${ }^{1}$ Department of Pharmacology, University of Aarhus, Aarhus, Denmark, ${ }^{2}$ Department of Theoretical Statistics Department of Mathematical Sciences, University of Aarhus, Aarhus, Denmark, ${ }^{3}$ Steno Diabetes Center, Gentofte, Denmark, ${ }^{4}$ Diabetes Research Unit, Novo Nordisk A/S, Måløv, Denmark and ${ }^{5}$ Mellitech, INAC/SCIB/, CEA Grenoble, France

Email: Lærke Egefjord - le@studmed.au.dk; Jens Ledet Jensen - jlj@imf.au.dk; Claus Heiner Bang-Berthelsen - clbb@steno.dk; Andreas Brønden Petersen - Andreas.Petersen@studmed.au.dk; Kamille Smidt - kcjs@farm.au.dk; Ole Schmitz - os@farm.au.dk; Allan Ertman Karlsen - aek@novonordisk.com; Flemming Pociot - fpoc@steno.dk; Fabrice Chimienti - f.chimienti@mellitech.com; Jørgen Rungby - jr@farm.au.dk; Nils E Magnusson* - nm@farm.au.dk

* Corresponding author

\section{Published: 25 February 2009}

BMC Endocrine Disorders 2009, 9:7 doi:10.1186/1472-6823-9-7

This article is available from: http://www.biomedcentral.com/I472-6823/9/7

(c) 2009 Egefjord et al; licensee BioMed Central Ltd.

This is an Open Access article distributed under the terms of the Creative Commons Attribution License (http://creativecommons.org/licenses/by/2.0), which permits unrestricted use, distribution, and reproduction in any medium, provided the original work is properly cited.
Received: 7 November 2008

Accepted: 25 February 2009

\begin{abstract}
Background: $\beta$-cells are extremely rich in zinc and zinc homeostasis is regulated by zinc transporter proteins. $\beta$-cells are sensitive to cytokines, interleukin-I $\beta$ (IL-I $\beta$ ) has been associated with $\beta$-cell dysfunction and -death in both type I and type 2 diabetes. This study explores the regulation of zinc transporters following cytokine exposure.
\end{abstract}

Methods: The effects of cytokines IL-I $\beta$, interferon- $\gamma$ (IFN- $\gamma$ ), and tumor necrosis factor- $\alpha$ (TNF$\alpha)$ on zinc transporter gene expression were measured in INS-I-cells and rat pancreatic islets. Being the more sensitive transporter, we further explored ZnT8 (Slc30A8): the effect of ZnT8 over expression on cytokine induced apoptosis was investigated as well as expression of the insulin gene and two apoptosis associated genes, BAX and BCL2.

Results: Our results showed a dynamic response of genes responsible for $\beta$-cell zinc homeostasis to cytokines: IL-I $\beta$ down regulated a number of zinc-transporters, most strikingly ZnT8 in both islets and INS-I cells. The effect was even more pronounced when mixing the cytokines. TNF- $\alpha$ had little effect on zinc transporter expression. IFN- $\gamma$ down regulated a number of zinc transporters. Insulin expression was down regulated by all cytokines. ZnT8 over expressing cells were more sensitive to IL-I $\beta$ induced apoptosis whereas no differences were observed with IFN$\gamma$, TNF- $\alpha$, or a mixture of cytokines.

Conclusion: The zinc transporting system in $\beta$-cells is influenced by the exposure to cytokines. Particularly ZnT8, which has been associated with the development of diabetes, seems to be cytokine sensitive. 


\section{Background}

The zinc content of pancreatic $\beta$-cells is among the highest in the body [1] and zinc plays an important structural role in many proteins by binding protein molecules in dimers and, in the case of insulin, in oligomers. Insulin is stored as hexameric complexes chelating two zinc ions within vesicles in a crystalline state [2]. Furthermore, zinc is an important determinant of $\beta$-cell survival and a co-factor in metalloenzymes and zinc-dependent transcription factors $[3,4]$. Evidence that $\beta$-cell derived zinc is a major regulator of glucagon secretion is emerging $[5,6]$. Finally, the activity of $\beta$-cell L-type calcium channels, involved in insulin secretion, is partly regulated by zinc [7].

Diabetes affects zinc homeostasis [8] resulting in hypozincaemia, hyperzincuria and, most likely, a generalized zinc deficiency $[2,9,10]$. We have previously shown that the zinc content of $\beta$-cells is glucose dependent [11].

Regulation of zinc homeostasis is ensured by zinc transporters assigned to two metal transporter families: the ZIP proteins (SLC39a) and the ZnT proteins (SLC30a). ZIPs facilitate influx of zinc to the cytosol from the outside of cells or from the lumen of intracellular compartments while ZnTs ensure zinc efflux from cytosol to the outside of cells or to intracellular organelles [12]. The mammalian ZIP family comprises 14 proteins and the ZnT family 10 proteins, respectively [13]. The expression of a number of zinc transporters depend on ambient glucose concentrations $[14,15]$. Zinc levels are higher in ZnT8 over expressing cells with a higher zinc accumulation capacity and an enhanced glucose mediated insulin secretion. Furthermore, over expression of this protein has been reported to protect cultured $\beta$-cells from cell death induced by zinc depletion [16]. In the brain, the lack of specific zinc transporters, particularly ZnT3, is associated with apoptosis and amyloid deposition [17]. Sladek et al. [18] identified polymorphisms in the SLC30a8 gene encoding for the zinc transporter ZnT8 as a major genetic risk factor for the development of Type 2 diabetes, this was recently confirmed [19-21]. ZnT8 also appears to be a major humoral autoantigen involved in the pathogenesis of type 1 diabetes [22]. No genetic association between SLC30A8 and type 1 diabetes has been found $[23,24]$.

Cytokines are well known mediators of cell death in the mature $\beta$-cell. This is due to the downstream signaling events orchestrated by the main inflammatory cytokines, TNF- $\alpha$, IFN- $\gamma$, and IL1- $\beta[25,26]$. IL- $1 \beta$ alone or in combination with TNF- $\alpha$ and/or IFN- $\gamma$ is toxic to $\beta$-cells in rat, mouse, and human islets and is in part mediated by transcriptional changes in the $\beta$-cells [27]. Destruction of $\beta$ cells is induced by highly reactive agents both oxygen derived free radicals and nitric oxide (NO) [8], which increase apoptosis [28] and decrease insulin production and release [29]. IL-1 $\beta$ is known to facilitate transcription of inducible NO-synthase (iNOS) by the activation of NFkB [30]. Data suggest that islets exposed to IL-1 $\beta$ have an impaired first phase insulin secretion [31]. Stimulation or over expression of different defense mechanisms protects $\beta$-cells against the toxic effect of cytokines [32-34]. Thus glucose responsive $\beta$-cells seem to be protected by anti apoptotic proteins. It has been shown that exposure to IL-1 $\beta$ and IFN- $\gamma$ causes down regulation of the antiapoptotic protein $\mathrm{Bcl} 2$ before the onset of apoptosis [35]. On the other hand, it has been established that the Bax protein promotes apoptosis in the $\beta$-cell [36].

Here we aim to explore whether cytokines influence zinc transporter expression and to provide a profile of the alterations. Having defined the more sensitive transporter, ZnT8, we explore the effects of over expression on the outcome of cytokine exposure to $\beta$-cells. We thus examine the hypothesis that the toxic effects of cytokines include regulation of zinc transporter genes.

\section{Methods \\ Cell cultures}

INS- 1 and INS-1E cells were cultured in a $5 \% \mathrm{CO}_{2}$ atmosphere in complete RPMI 1640 supplemented with $11 \mathrm{mM}$ glucose, $10 \%$ heat-inactivated fetal bovine serum, $50 \mu \mathrm{M}$ beta-mercaptoethanol, $2 \mathrm{mM}$ L-Glutamine, $100 \mathrm{U} / \mathrm{mL}$ penicillin, and $100 \mathrm{~g} / \mathrm{mL}$ streptomycin. For stimulation assays cells were plated $\left(10^{6} \mathrm{cells} /\right.$ well $)$ into 6 -well plates (NUNC, Roskilde, Denmark). The INS-1 cells were treated with 60-180 U recombinant mouse IL- $1 \beta / \mathrm{mL}, 200 \mathrm{U}$ TNF- $\alpha / \mathrm{mL}, 200 \mathrm{U}$ recombinant Rat IFN $-\gamma / \mathrm{mL}$ or a mixture, consisting of $180 \mathrm{U}$ IL- $1 \beta / \mathrm{mL}, 200 \mathrm{U}$ TNF- $\alpha / \mathrm{mL}$ and 200 U Rat IFN- $\gamma / \mathrm{mL}$ (PharMingen International, San Diego, CA, USA). For INS-1 cells treatments were given for 1 and 24 hours, in replicas of 6 . For INS-1E and INS-1EZnT8-EGFP cells treatments were given for 6 and 24 hours in replicas of 3. Controls were incubated with RPMI 1640 medium and $11 \mathrm{mM}$ glucose. The stably transfected cell line INS-1E-ZnT8-EGFP was maintained as described above with the addition of $75 \mu \mathrm{M}$ G418 to maintain a pure culture of cells expressing the ZnT8-EGFP construct. Expression of the fusion protein was controlled by fluorescence microscopy and by Q-PCR using ZnT8-EGFP specific primers (figure 1) [16].

\section{Rat islet preparation}

Isolation and culturing of islets from 3-6 day old Wistar Furth rats (Charles River, Sulzfeldt, Germany) were as described [37]. The islets were precultured for 7 days in complete medium (RPMI 1640 with $100 \mathrm{U} / \mathrm{mL}$ penicillin and $100 \mu \mathrm{g} / \mathrm{mL}$ streptomycin and $11 \mathrm{mM}$ glucose) supplemented with $10 \%$ newborn calf serum (Invitrogen/Gibco, Denmark). Five hundred randomly picked islets were used per $1 \mathrm{~mL}$ of complete medium supplemented with 

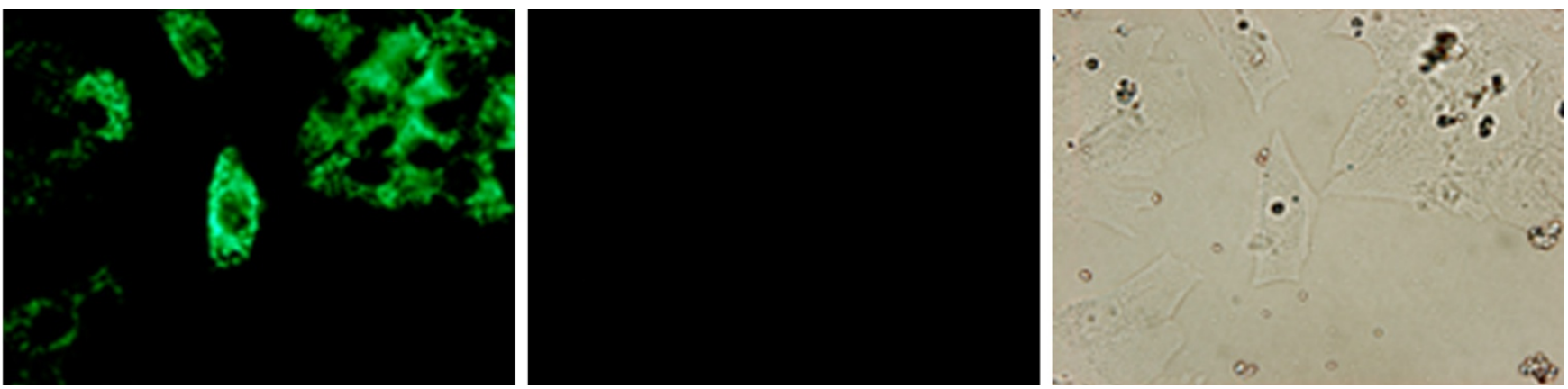

Figure I

Transfection of INS-I E cells with human ZnT8: Left panel shows fluorescence (green) marked ZnT8 RNAprobe positivity in transfected cells, contrasting the void control cells, middle panel. Right panel shows the light microscopic appearance of the same cells.

$0.5 \%$ human serum and $11 \mathrm{mM}$ glucose. Islets were placed in 12-well plates (NUNC, Roskilde, Denmark), one plate for each time point. Cytokine treatments were given for 1, 2, 4, 6 and 24 hours in replicates of 4 . Treatments were with $250 \mathrm{pg} / \mathrm{mL}$ IL- $1 \beta / \mathrm{mL}, 10 \mathrm{ng} / \mathrm{mL}$ IFN- $\gamma$ or a mixture, consisting of $250 \mathrm{pg} / \mathrm{mL} \mathrm{IL}-1 \beta$ and $10 \mathrm{ng} / \mathrm{mL}$ IFN- $\gamma$. Controls were incubated for 24 hours at identical conditions without addition of cytokines. At the end of the stimulation periods the islets were transferred to Eppendorf tubes for RNA isolation.

\section{Isolation of total RNA}

For INS-1E cells total RNA was isolated using RNeasy Mini Kit 8 (Qiagen) according to the manufacturer's instructions. For archive material (islets and INS-1 cells) total RNA was isolated using TriZol. In brief, each sample was dissolved in $1 \mathrm{~mL}$ Trizol ${ }^{\circledR}$ reagent (Invitrogen) on ice. Trizol was removed by addition of chloroform followed by isopropanol precipitation. The precipitates were washed using 75\% ethanol. The amount and purity of total RNA was quantified using photospectrometry by measuring the optical density at 260 and $280 \mathrm{~nm}$ and the integrity was checked by agarose gel electrophoresis.

\section{Real time polymerase chain reaction \\ TaqMan assay}

cDNA synthesis of archive (islets and INS-1 cells) material was performed using the RT-PCR TaqMan Kit N808-0234 (Perkin Elmer) according to the manufacturer's instructions. RefSeq IDs used for primer design and TaqMan IDs are listed in table 1. For the PCR-assay, $200 \mathrm{ng}$ total RNA was used as starting material for the CDNA preparation in a reaction volume of $7.7 \mu \mathrm{L}$. Semi-quantitative RT-PCR was carried out in $20 \mu \mathrm{L}$ reaction containing $2 \mu \mathrm{L}$ TaqMan RT Buffer, $4.4 \mu \mathrm{L} 25$ mM MgCl2, $4 \mu \mathrm{L}$ dNTP $(200 \mu \mathrm{M}), 1$ $\mu \mathrm{L}$ random hexamer $(100 \mathrm{pmol} / \mu \mathrm{L}), 0.4 \mu \mathrm{L}$ RNAse Inhibitor, $0.5 \mu \mathrm{L}$ MultiScribe Reverse Transcriptase $(50 \mathrm{U} / \mu \mathrm{L})$,
$0.2 \mu \mathrm{L}$ RNase free water and $7.7 \mu \mathrm{L}$ RNA. Following reverse transcription cDNA solutions were incubated for 5 min at $95^{\circ}$ to inactivate transcriptase and then stored at $20^{\circ}$.

RT-PCR was carried out in a volume of $20 \mu \mathrm{L}$ per well in a 384-Well Optical Reaction Plates (A300990x) containing $1.0 \mu \mathrm{L}$ TaqMan Expression Assay, 5.0 $\mu \mathrm{L}$ RNase free water, 10.0 $\mu$ L TaqMan Universal PCR MasterMix $(2 \times)$ (without AmpErase UNG) and $4.0 \mu \mathrm{L}$ cDNA template. The plate was run on the Applied Biosystems 7900 HT Fast Real Time PCR System. The following protocol was used: $95^{\circ}$ in $10 \mathrm{~min}$ for AmpliTaq Gold Enzyme Activation and finally the PCR including 40 cycles with $95^{\circ}$ in $15 \mathrm{sec}$ for denaturation and $60^{\circ}$ in $1 \mathrm{~min}$ for annealing. To compensate for variation in CDNA concentrations and PCR efficiency between tubes, an endogenous control (beta-Actin) was included for each sample and used for normalisation.

\section{SYBR Green assay}

SYBR Green assay was used for experiments in INS-1E cells. Reverse transcription was performed on $500 \mathrm{ng}$ total RNA for $1 \mathrm{~h}$ at $42^{\circ} \mathrm{C}$ by using a T7-oligo(dT)24 primer and Superscript II reverse transcriptase (Life Technolo-

Table I: Primer sets used for real-time PCR; TaqMan assays were based on RefSeq ID.

\begin{tabular}{lll}
\hline Gene & RefSeq ID & TaqMan ID \\
\hline ZnT3 & NM_00I0I3243.I & RNOI472605_gl \\
ZnT4 & NM_I72066 & RN0I485635_m I \\
ZnT5 & XM_226722.4 & RN0I493869_m I \\
ZnT6 & XM_216643.4 & RNOI472402_m I \\
ZnT8 & XM_00I065623.I & RN0I504406_m I \\
Zip5 & XM_343I40.3 & RN0I527I66_gl \\
Zip6 & NM_00I024745 & RN0I405805_m I \\
beta-Actin & NM_03II44.2 & RN0I4I2977_gl
\end{tabular}


gies). Cycling was performed using an ICycler from Bio$\mathrm{Rad}$ as previously described. Whenever possible the primers were placed in exons separated by an intron of at least $500 \mathrm{bp}$. To avoid pseudogenes, at least one of the primers was placed in a region distinct from these. To confirm that the primer pairs produced only unique products, a dissociation protocol was performed after thermocycling, thereby determining the dissociation of the PCR products from $65^{\circ} \mathrm{C}$ to $95^{\circ} \mathrm{C}$. The real-time PCR assay included a no-template control and a standard curve of five serial dilution points (in steps of 10-fold) of a pool of the sampled cDNAs. All samples were amplified in duplicate.

\section{Quantification}

Normalised Ct 's were calculated by subtracting the Ctmean of the normalisation genes for each sample and relative $\log 2$ fold changes were calculated using the comparative delta-delta $\mathrm{C}_{\mathrm{t}}$ method [38].

\section{Cell death assays}

\section{MTT assay}

Cells were plated in 96-well plates and allowed to attach for $72 \mathrm{~h}$. INS-1E and INS-1E-ZnT8-EGFP cells were then treated with cytokines or control condition (no addition of cytokines) for 6,12 , and $24 \mathrm{~h}$. Each condition was performed in replicates of six. The experiment was repeated using cells grown from frozen stocks. The viability of each experimental condition was determined using the MTT [3(4,5-dimethylthiazol-2-yl)-2,5-diphenyltetrazolium bromide] assay based on the activity of mitochondrial reductase enzymes. The assay was performed according to the manufacturer's instructions (Roche). Briefly, following experimental treatment, $10 \mu \mathrm{L}$ of MTT solution was added to the culture medium and the plate was incubated in the dark for 3 hours at $37^{\circ} \mathrm{C}$. A solubilisation buffer $(100 \mu \mathrm{L})$ was added and allowed to incubate overnight at $37^{\circ} \mathrm{C}$. Absorbance was measured at $570 \mathrm{~nm}$ using a ELX 808 microplate reader (Bio-Tek Instruments inc.). The percentage viability was calculated as follows: relative specific viability $=[(\mathrm{A}-\mathrm{B}) /(\mathrm{C}-\mathrm{B})] \times 100$ where $\mathrm{A}=\mathrm{ABS} 570$ of the treated sample, $\mathrm{B}=\mathrm{ABS} 570$ of the medium, and $\mathrm{C}=$
ABS570 of the control. The values were expressed as viability relative to control for each cell line.

\section{Apoptosis/Necrosis assay}

Cells were plated and treated as described in the MTT assay section and cell death was measured using the Cell Death Detection ELISA-plus assay (Roche) according to the manufacturer's instructions. Following experimental treatment culture supernatants were isolated and the cells were harvested in lysis buffer. After centrifugation culture supernatants and cell lysates were used to determine the amount of necrosis and apoptosis, respectively, in a quantitative sandwich-enzyme-immunoassay. Absorbance was measured at $405 \mathrm{~nm}$ and the viability was calculated as described in the MTT section. The assay was repeated twice as described above.

\section{Statistical analyses}

Date are presented as means +/- s.e.m.. Anova analyses were performed to include a plate effect in INS-1 cells. Statistical significance of differences between stimulation and control was found using Student's t-tests. Anova analyses were performed on islet data. For the cell death assays results were considered significant at $\mathrm{p}<0.01$ in repeated experiments.

\section{Results}

Significant differences between cytokine treated and control INS-1 cells are listed in table 2. Cytokines mostly down regulated zinc transporter expression. The down regulation in most cases increased over time. TNF- $\alpha$ treatment had almost no effect, whereas IL- $1 \beta$, IFN- $\gamma$, and a mixture of cytokines all gave rise to down regulations of some of the genes. ZnT6 and ZnT8 were down regulated at both 1 and 24 hours, whereas ZnT3 was down regulated at 24 hours only. ZnT5 and Zip5 expression seemed not to be affected by cytokines and ZnT4 was only weakly influenced. Finally, Zip6 was influenced by IL-1 $\beta$ stimulation only, and at 24 hours only. A mixture of cytokines generally increased the down regulation.

Table 2: Regulation of ZnT/Zip expression in INS-I cells following cytokine exposure.

\begin{tabular}{|c|c|c|c|c|c|c|c|c|c|}
\hline & $\mathrm{IL}-\mathrm{I} \beta / 6 \mathrm{~h}$ & IL-I $\beta / 24 \mathrm{~h}$ & TNF- $\alpha / 6 \mathrm{~h}$ & TNF- $\alpha / 24 \mathrm{~h}$ & IFN- $\gamma / 6 \mathrm{~h}$ & $\mathrm{IFN}-\gamma / 24 \mathrm{~h}$ & Mix./6 h & Mix./24 h & SEM \\
\hline $\mathrm{ZnT3}$ & 0.00 & $-0.58 * *$ & -0.14 & 0.00 & -0.14 & $-0.93 * *$ & -0.14 & $-1.85 * *$ & $+/-0.20$ \\
\hline ZnT4 & -0.38 & 0.00 & -0.14 & $0.49 *$ & $-0.49 *$ & $-0.38^{*}$ & $-0.49 *$ & 0.26 & $+/-0.19$ \\
\hline ZnT5 & -0.14 & 0.00 & 0.00 & 0.26 & -0.38 & -0.38 & -0.38 & -0.26 & $+/-0.23$ \\
\hline ZnT6 & $-0.26 * *$ & $-0.26 * *$ & -0.14 & 0.00 & $-0.26 * *$ & $-0.26^{*}$ & $-0.14^{*}$ & -0.14 & $+/-0.09$ \\
\hline ZnT8 & $-0.38^{*}$ & 0.26 & -0.14 & 0.26 & $-0.49 * *$ & $-0.38^{* * *}$ & $-0.49 * *$ & $-1.81 * *$ & $+/-0.16$ \\
\hline Zip5 & 0.00 & -0.14 & -0.14 & 0.38 & 0.14 & $-0.77^{*}$ & -0.26 & -0.38 & $+/-0.36$ \\
\hline Zip6 & -0.00 & $-0.85 * *$ & 0.00 & 0.00 & -0.26 & $0.38^{*}$ & -0.14 & -1.00 ** & $+/-0.15$ \\
\hline
\end{tabular}

Log2-fold changes are indicated $(n=6)$. (* $p<0.05$, ** $p<0.01)$. Mix. is IL-I $\beta+T N F-\alpha+I F N-\gamma$ IL-I $\beta$. The last column indicates standard errors $+/-$ SEM for log2 fold changes. 
In islets there was no change over time for IFN- $\gamma$ stimulation, whereas ZnT6 and ZnT8 showed significant changes over time for both IL- $1 \beta$ and the stimulation with IL- $1 \beta+$ IFN- $\gamma$ (table 3 ). There were significant differences between the three treatments at 24 hours for ZnT5, ZnT6 and ZnT8 (table 4). Figure 2 shows the time course for the difference between the IL- $1 \beta$ stimulation and the IFN- $\gamma$ stimulation for ZnT5, ZnT6, ZnT8, Zip5 and Zip6. For these genes there was a systematic development over time. As in INS1 cells a mixture of cytokines generally increased the down regulation. Cytokine stimulation for 24 hours resulted in an overall down regulation of the insulin gene in islets and INS-1 cells (results not shown). As for INS-1 cells, ZnT8 was the most regulated zinc transporter in islets where it was down regulated approximately 12 fold ( 3.5 on a $\log 2$ scale).

The sensitivity to cytokines in INS-1E and INS-1E-ZnT8EGFP cells was estimated by measuring mitochondrial activity (figure 3). No differences between the cell lines were found after exposure to TNF- $\alpha$. Compared to INS-1E, IFN- $\gamma$ decreased survival after 6 hours (but not after 12 or 24 hours). IL-1 $\beta$ decreased survival after 12 and 24 hours. Cytokine mixtures decreased survival after 6 hours (but not after 12 or 24 hours). These results were verified by an independent assay specifically measuring apoptosis and necrosis at 12,24 , and 36 hours with IL-1 $\beta$ and cytokine mixture. Apoptosis was increased by 4 and 2 fold in the ZnT8 transfected cell line following treatment with IL-1 $\beta$ for 24 and 36 hours, respectively (table 5). No differences were observed between the cell lines using the cytokine mixture. In addition, BCL2 and BAX mRNA expressions were compared between the cell lines at 6 and 24 hours (figure 4). Two of the housekeeping genes (beta-Actin and Cyclophilin A) showed a marked difference between the two cell lines and the two time points. Expression of the housekeeping gene UBC7 showed no difference between the two cell lines and a minor difference between the two time points. None of the housekeeping genes showed a difference between the treatments. UBC7 was therefore used as the normalizing gene. BAX and BCL2 showed no

Table 3: Regulation of ZnT/Zip expression in islets following cytokine exposure $(n=4)$.

\begin{tabular}{lccc}
\hline & IL-I $\beta$ & IFN- $\gamma$ & IL-I $\beta+$ IFN- $\gamma$ \\
\hline ZnT3 & $0.7^{*}$ & 30.5 & 38.9 \\
ZnT4 & 86.3 & 62.9 & 17.9 \\
ZnT5 & 7.0 & 67.7 & $0.1^{*}$ \\
ZnT6 & $1.40^{*}$ & 31.7 & $1.4^{*}$ \\
ZnT8 & $0.0^{*}$ & 50.9 & $0.0^{*}$ \\
Zip5 & 14.6 & 88.1 & 52.8 \\
Zip6 & 27.0 & 55.4 & 41.5
\end{tabular}

P-values in percent for the hypothesis of no change over time are given. $(*)$ p-values below $5 \%$ are highlighted.
Table 4: Regulation of ZnT/Zip expression in islets following cytokine exposure $(n=4)$.

\begin{tabular}{lccccc}
\hline & $\mathrm{I} \mathrm{h}$ & $2 \mathrm{~h}$ & $4 \mathrm{~h}$ & $6 \mathrm{~h}$ & $24 \mathrm{~h}$ \\
\hline ZnT3 & 87.7 & 51.3 & 11.5 & $1.6^{*}$ & 25.2 \\
ZnT4 & 40.8 & 69.8 & 54.0 & 36.9 & 25.8 \\
ZnT5 & 62.5 & 99.3 & 50.9 & 22.4 & $1 . I^{*}$ \\
ZnT6 & 86.9 & 80.6 & 77.3 & 18.0 & $1.1^{*}$ \\
ZnT8 & 76.5 & 75.7 & 46.3 & $0.8^{*}$ & $0.0^{*}$ \\
Zip5 & 82.7 & 84.7 & 74.2 & 62.4 & 10.9 \\
Zip6 & 55.6 & 90.8 & 80.3 & 26.5 & 5.0 \\
\hline
\end{tabular}

$\mathrm{P}$-values in percent for the hypothesis of no difference between treatments are given. $\left(^{*}\right)$ p-values below $5 \%$ are highlighted.

response to cytokine treatment ( $\mathrm{p}=0.07$ and $\mathrm{p}=0.13$ ), but both genes showed a strong time effect $(\mathrm{p}<0.0001$ and $\mathrm{p}=0.0001$ ), and BAX exhibited a higher expression in the INS-1E-ZnT8-EGFP cells $(\mathrm{p}<0.0001)$. Insulin gene expression showed a difference between the two cell lines and a difference between the two time points. On top of that IL-1 $\beta$ decreased the expression of insulin in INS-1EZnT8-EGFP cells $(\mathrm{p}=0.0001)$ and a mixture of cytokines decreased the expression for both cell lines ( $p<0.0001)$.

\section{Discussion}

The present study demonstrates that cytokines regulate the expression of zinc transporter mRNA in $\beta$-cells. This may relate to both loss of cell mass (as is the case in the central nervous system [17]) and to decreased secretory capacity [16]. Evidence that zinc homeostasis is important for the development of diabetes is emerging from a number of association studies [18-20,22]. Zinc is concentrated in islet cells and related to insulin synthesis, storage and secretion [39]. Hypozincemia is a common feature in diabetes [40,41] and zinc supplementation has been shown to inhibit the development of experimental type 1 diabetes in mice [42]. Moreover, zinc can improve hyperglycemia in streptozotocin-diabetic mice [34]. We have previously described that some, but not all, ZnTs and ZIPs are influenced by ambient glucose levels and zinc concentrations in $\beta$-cells, suggesting an active role for these proteins. ZnT3 and ZnT8 appear to be of particular interest $[14,15]$.

In the present study, cytokines generally down regulated the expression of zinc transporters in both islets and INS1 cells and we found an increased regulation over time. In most cases, zinc transporter expression was similar for INS-1 cells and islets but of greater magnitude in islets. Some of the discrepancies may be due to the presence of other cell types in islets. Also, TNF- $\alpha$ was not tested in islets limiting the conclusions for this cytokine. Comparing individual cytokines showed that some zinc transporters, namely ZnT5, ZnT6 and ZnT8, exhibited similar expression profiles indicating that these transporters may 


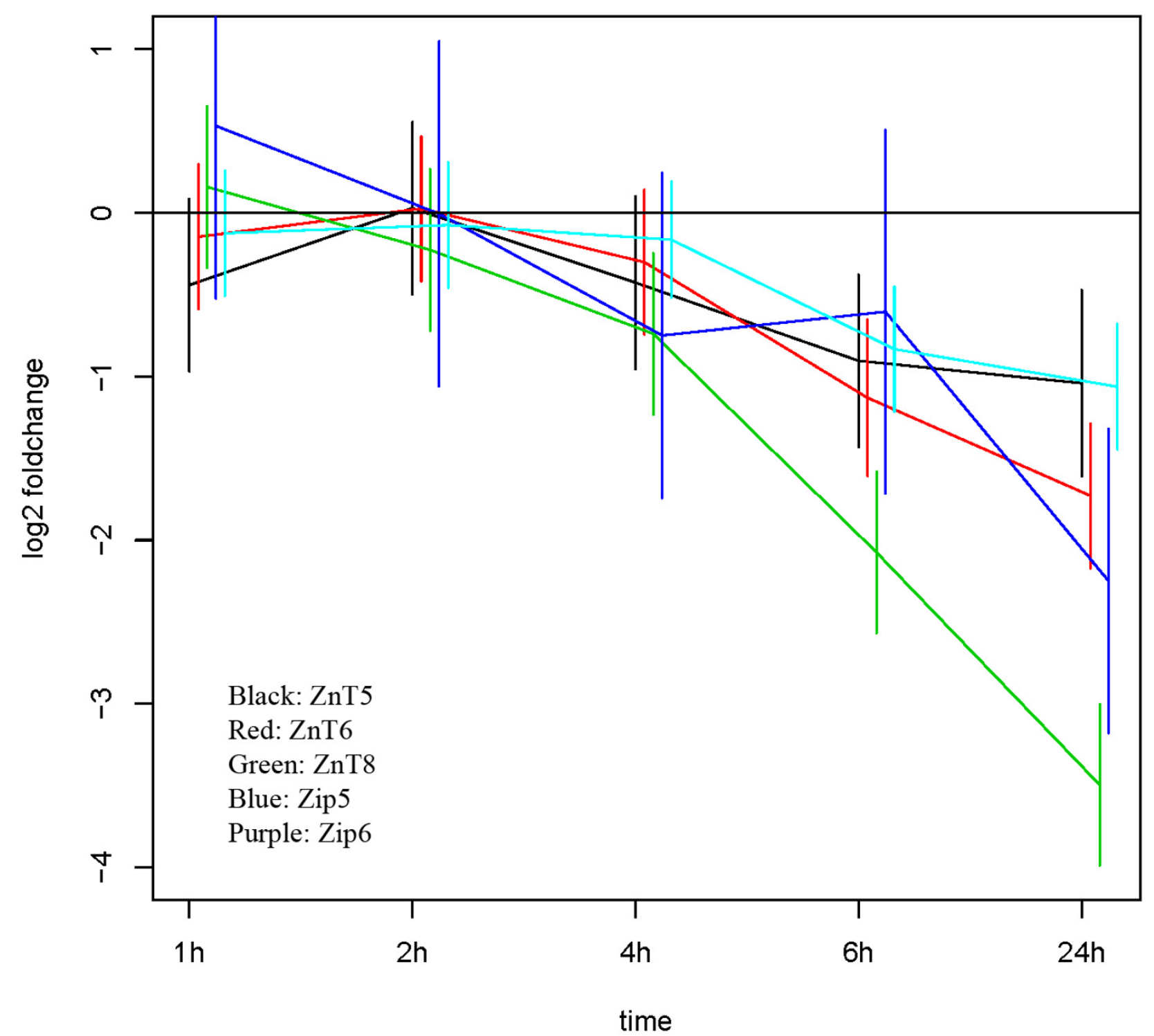

Figure 2

Zinc transporter expression profiles for ZnT5, ZnT6, ZnT8, Zip5, and Zip6 following cytokine exposure in islets. The figure shows the time course for the log2 difference $+/$ - SEM between the IL-I $\beta$ stimulation and the IFN- $\gamma$ stimulation, showing a systematic development over time for the indicated genes. $(n=4)$. Black; ZnT5, red; ZnT6, green; ZnT8, blue; Zip5, purple; Zip6.

share regulatory transcriptional mechanisms [43]. The mixture of cytokines, mimicking the in vivo cytokine load in islet inflammation, augmented the responses seen with the individual cytokines. Notably ZnT8 responded with very large significant down regulations to both IL-1 $\beta$ and the cytokine mixture. Excessive apoptosis of pancreatic $\beta$ cells has been associated with diabetes [44]. It has been shown that zinc depletion by itself can induce apoptosis [45] and it may also promote apoptosis induced by oxidative stress [46], thereby participating in reduction of $\beta$-cell 
Table 5: Induction of apoptosis/necrosis in INS-IE-ZnT8-EGFP cells relative to INS-IE cells following cytokine exposure $(n=3)$.

\begin{tabular}{|c|c|c|c|c|c|c|}
\hline & $\mathrm{IL}-\mathrm{I} \beta / \mathrm{I} 2 \mathrm{~h}$ & IL-I $\beta / 24 \mathrm{~h}$ & IL-I $\beta / 36 \mathrm{~h}$ & $\mathrm{Mix} / \mathrm{I} 2 \mathrm{~h}$ & Mix/24 h & $M i x / 36 \mathrm{~h}$ \\
\hline Apoptosis & - & $* 4.1+/-0.21$ & $* 1.8+/-0.23$ & - & - & - \\
\hline Necrosis & - & - & - & - & - & - \\
\hline
\end{tabular}

Data represent mean of two independent experiments. Fold changes between cell lines are indicated. $(*) \mathrm{p}<0.05$ in both experiments. Only significant changes are shown $+/$ - SEM. Mix. is IL-I $\beta+$ TNF- $\alpha+$ IFN- $\gamma$ IL-I $\beta$.

mass. Enhanced capacity of the $\beta$-cell to store zinc may therefore protect against zinc depletion and oxidative stress [16]. On the other hand, some of the changes in intracellular zinc concentrations that can be expected from the changes in transporter expression described here might increase the intracellular load of free zinc ions and may add yet another mechanism for cell death since it has previously been demonstrated that an exaggerated transmembrane zinc transport can severely affect beta-cell survival by a direct toxic effect of zinc [47].

\section{IL-1 $\beta$ exposure \\ INS-1E vs. INS-1E-ZnT8-EGFP}

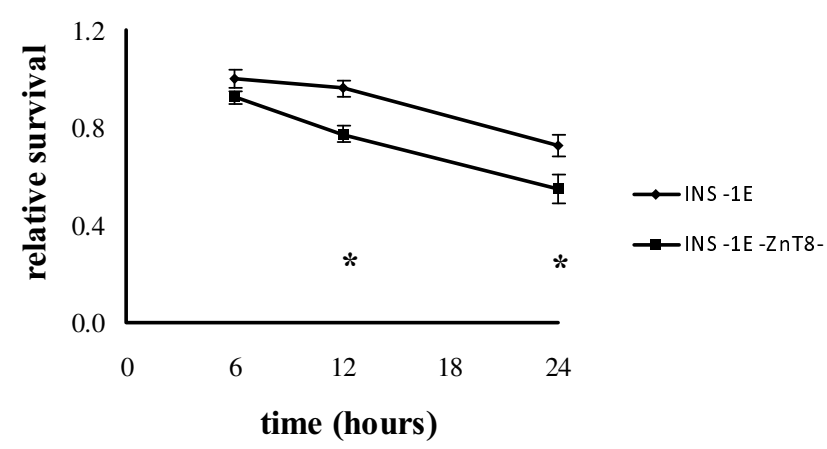

IFN- $\gamma$ exposure

INS-1E vs. INS-1E-ZnT8-EGFP

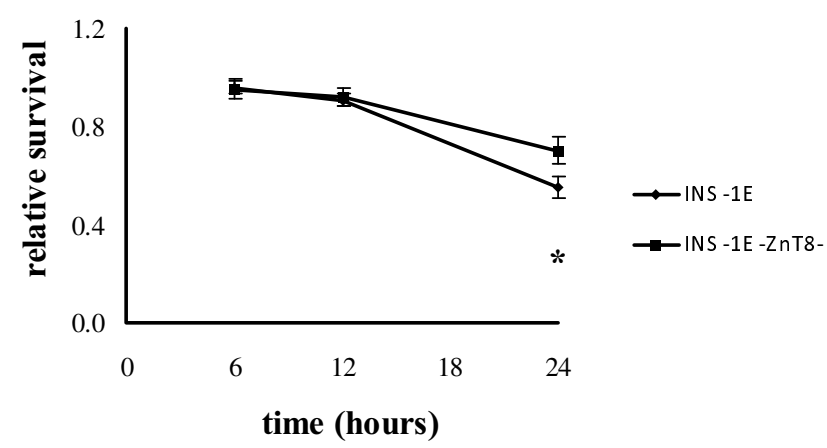

Evidence suggests that ZnT8 enhances zinc storage in insulin granules and is directly implicated in the insulin secretion pathway. In this study we found that INS-1E cells over expressing ZnT8 were more sensitive to IL-1 $\beta$ induced apoptosis. Interestingly, compared to wild type cells, the cytokines IFN- $\gamma$ and TNF- $\alpha$ as well as the cytokine mixture did not result in increased apoptosis, suggesting that ZnT8 may be affected by signalling pathways regulated by IL-1 $\beta$. Palmer et al. [48] showed that sensitivity towards IL-1 $\beta$ depends on the metabolic status

TNF- $\alpha$ exposure

INS-1E vs. INS-1E-ZnT8-EGFP

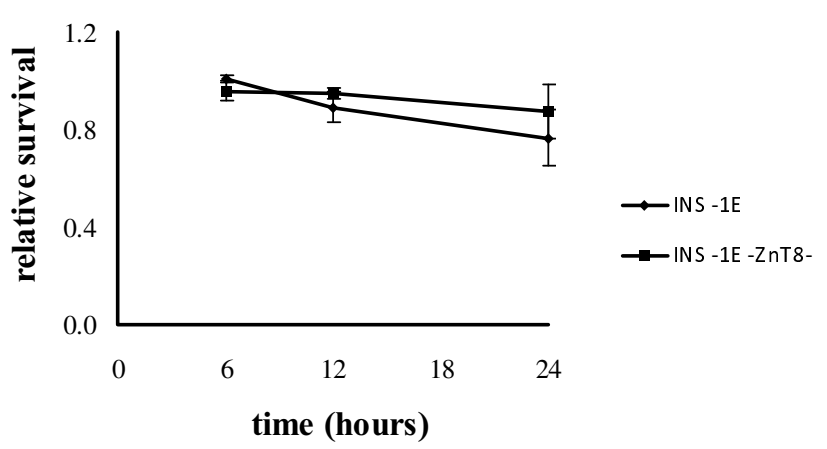

\section{IL-1 $\beta+$ TNF- $\alpha+$ IF $N-\gamma$ exposure INS-1E vs. INS-1E-ZnT8-EGFP}

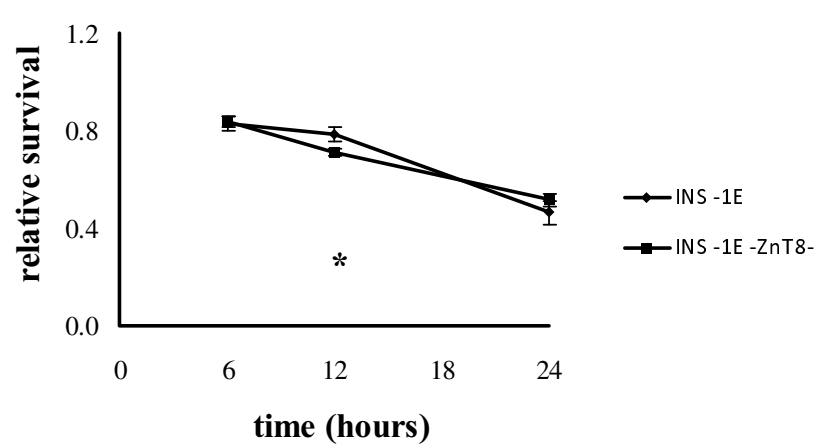

Figure 3

Relative survival for INS-IE and INS-IE-ZnT8-EGFP cells following cytokine exposure after 6, I 2, and 24 hours was estimatedby MTT. Values were calculated relative to control cells for each cell line $+/-$ SEM $(n=6)$. $(*) p<0.0 \mathrm{I}$ indicates significance in two independent experiments. 

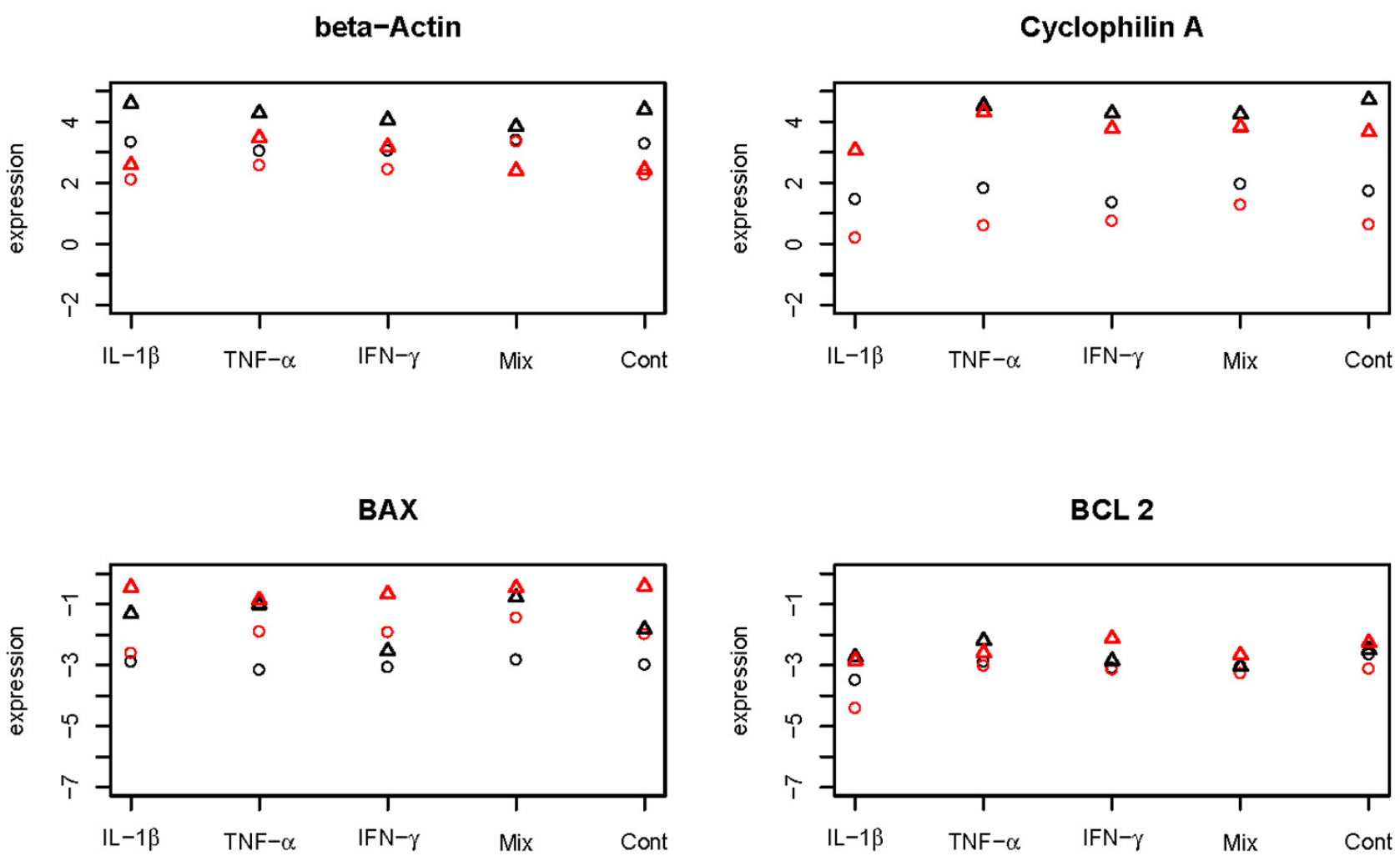

\section{Insulin}
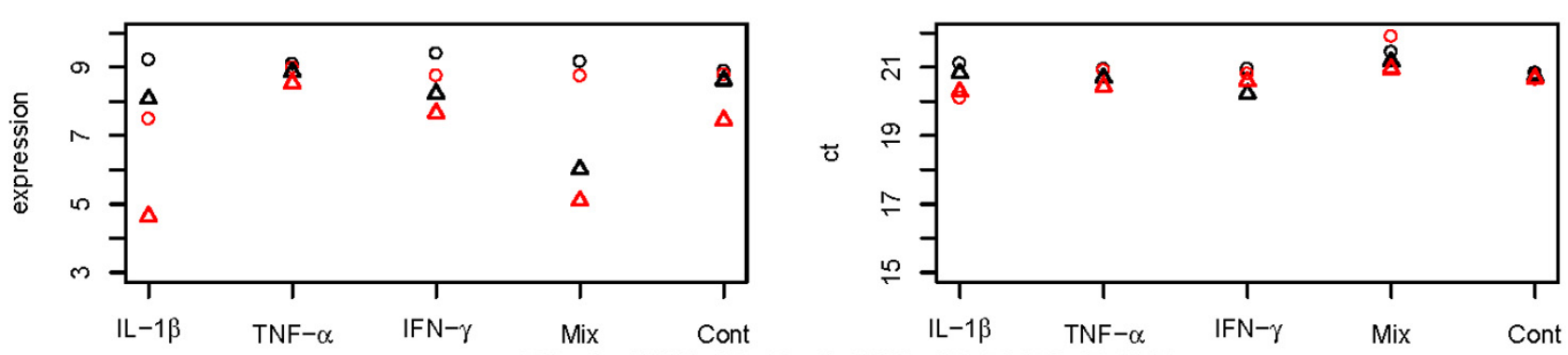

Black; INS-1E, Red; INS-1E-ZnT8-EGFP,

Circles; 6 hours, Triangles; 24 hours

\section{Figure 4}

Log2 expression levels relative to UBC7 for beta-Actin, Cyclophilin A, BAX, BCL2, and insulin in INS- IE and INS-I E-ZnT8-EGFP cells $(\mathbf{n}=\mathbf{3})$. The last plot indicates the expression level of the normalizing gene UBC7. Black; INS- IE cells, red; INS-IE-ZnT8-EGFP cells. Circles; 6 hour treatments, triangles; 24 hour treatments.

of the $\beta$-cell indicating that over expression of ZnT8 may increase the metabolic activity. Hence, contrasting previous studies, over expression of ZnT8 was not protective with respect to cytokine exposure. However, siRNA knockdown of this gene seems to increase the sensitivity of INS$1 \mathrm{E}$ cells (unpublished observation) suggesting that the level of protein and specific stressor are important for the outcome. Cytokines mediate $\beta$-cell death by varying pathways and are instrumental in the reduction of $\beta$-cell mass in both type 1 and type 2 diabetes [49]. $\beta$-cell destruction is the result of islet infiltration and an inflammatory response elicited by secretion of pro-inflammatory 
cytokines and chemotactic factors leading to insulinopenia and hyperglycemia [50]. Both IL- $1 \beta$ and TNF- $\alpha$ contribute to pancreatic $\beta$-cell death in type 1 diabetes probably via activation of transcription factor nuclear factor-kappa-B (NF-kappaB). IL-1 $\beta$ is associated with a more severe induction of cell death compared to TNF- $\alpha$ and was also observed in the present study (data not shown). Recent studies suggest that these differences may partly be explained by a stronger induction of NF-kappaB and its target genes by IL-1 $\beta$ [51]. The ZnT8 over expressing cell line exhibited a higher basal level of apoptosis compared to control cells indicating an increased pro-apoptotic environment per se. In line with this, the relative expression of BAX (pro-apoptotic) was higher in the transfected cell line and no difference was found for BCL2 (anti-apoptotic). Expressions of the insulin gene were significantly down regulated by similar magnitudes in both cell lines corroborating previous observations [29].

\section{Conclusion}

In summary, the present study demonstrates for the first time that regulation of zinc transporters is sensitive to proinflammatory cytokines.

These data suggest that cytokines might contribute to the disturbed intracellular zinc homeostasis seen in $\beta$-cells of type 1 and type 2 diabetic patients. Furthermore, over expression of ZnT8 may sensitize INS-1E cells to apoptosis via IL- $1 \beta$ indicating a possible role for this protein in $\beta$ cell apoptosis. However, further mechanistic studies should be performed to determine the specific role for ZnT8 in the downstream events from IL-1 $\beta$ causing $\beta$-cell apoptosis.

\section{Competing interests}

The authors declare that they have no competing interests.

\section{Authors' contributions}

NEM and LE contributed to the conception, design, acquisition and analysis of data and wrote the manuscript. JLJ did the mathematical/statistical analyses. NEM and JLJ interpreted the results. $\mathrm{CHB}$ contributed to acquisition of data and made suggestions to the manuscript. ABP and KS contributed to acquisition of data. AEK, FP, FC, OS and JR contributed to the conception and made improvements to the manuscript.

\section{Acknowledgements}

Technical assistance was provided by Karen Skjoedt Soerensen and Elin Carstensen, Department of Pharmacology, Aarhus University, Denmark and Bodil Bosmann Jørgensen, Steno Diabetes Center, Gentofte, Denmark. This work was supported by grants from the Novo Nordisk Scholarship Programme, the Novo Nordisk Research Foundation, and the Danish Diabetes Association.

\section{References}

I. Clifford KS, MacDonald MJ: Survey of mRNAs encoding zinc transporters and other metal complexes from birth to adulthood: similar patterns in the Spraque-Dawley and Wistar BB Strains. Diabetes Research Clinical Practice 2000, 49:77-85.

2. Chausmer $A B$ : Zinc, insulin and diabetes. Journal of the American College of Nutrition 1998, 17:109-1 I5.

3. Vallee BL, Falchuk KH: The biochemical basis of zinc physiology. Physiological Reviews 1993, 73:9-118.

4. Kim BJ, Kim YH, Kim S, Kim JW, Koh JY, Oh SH, Lee MK, Kim KW Lee MS: Zinc as a paracrine effector in pancreatic islet cell death. Diabetes 2000, 49:367-372.

5. Ishihara $H$, Maechler P, Gjinovci A, Herrera PL, Wollheim CB: Islet $\beta$-cell secretion determines glucagon release from neighbouring alpha-cells. Nature Cell Biology 2003, 5:330-335.

6. Ashcroft F, Rorsman P: Type 2 diabetes mellitus: not quite exciting enough? Human Molecular Genetics 2004, I 3:R2 I-3 I.

7. Priel $T$, Hershfinkel $M$ : Zinc influx and physiological consequences in the $\beta$-insulinoma cell line, Min6. Biochem Biophys Res Commun 2006, 346:205-2I2.

8. Rabinovitch A, Suarez-Pinzon WL, Strynadka K, Lakey JR, Rajotte RV: Human pancreatic islet $\beta$-cell destruction by cytokines involves oxygen free radicals and aldehyde production. J Clin Endocrinol Metab 1996, 81:3197-202.

9. Kinlaw WB, Levine AS, Morley JE, Silvis SE, McClain C): Abnormal zinc metabolism in type II diabetes mellitus. American Journal of Medicine 1983, 75:273-277.

10. Pai LH, Prasad AS: Abnormal zinc metabolism in type II diabetes mellitus. Nutr Res 1988, 8:899-897.

II. Søndergaard LG, Stoltenberg M, Flyvbjerg A, Brock B, Schmitz O, Danscher $G$, Rungby J: Zinc ions in $\beta$-cells of obese, insulinresistant, and type 2 diabetic rats traced by autometallography. APMIS 2003, I I I: I I47-II54.

12. Kambe T, Yamaguchi-Iwai Y, Sasaki R, Nagao M: Overview of mammalian zinc transporters. Cell Mol Life Sci 2004, 6I:49-68.

13. Cousins RJ, Liuzzi JP, Lichten LA: Mammalian zinc transport, trafficking, and signals. Journal of Biological Chemistry 2006, 28I:24085-24089.

14. Magnusson N, Bjerre Knudsen LB, Wogensen L, Brock, Schmitz O, Egefjord L, Jeppesen JB, Rungby J: The long-acting GLP-I analogue liraglutide regulates zinc transporter mRNA in $\beta$ cells. 0/44 Diabetologia 2007, 50:565.

15. Jeppesen JB, Larsen A, Jessen N, et al.: Glucose and zinc-depletion stimulate beta cell expression of $\mathrm{ZnT3}$, a zinc transporter, whereas $\mathrm{ZnT3}$ KO mice have decreased beta cell capacity. Diabetologia 2007, 50:S207.

16. Chimienti F, Devergnas S, Pattou F, Schuit F, Garcia-Cuenca R, Vandewalle B, Kerr-Conte J, Van Lommel L, Grunwald D, Favier A, Seve M: In vivo expression and functional characterization of the zinc transporter ZnT8 in glucose-induced insulin secretion. Journal of Cell Science 2006, I 1 9:41 99-4206.

17. Stoltenberg M, Bush Al, Bach G, Smidt K, Larsen A, Rungby J, Lund S, Doering P, Danscher G: Amyloid plaques arise from zincenriched cortical layers in APP/PSI transgenic mice and are paradoxically enlarged with dietary zinc deficiency. Neuroscience 2007, 5:357-369.

18. Sladek R, Rocheleau G, Rung J, Dina C, Shen L, Serre D, Boutin P, Vincent D, Belisle A, Hadjadj S, Balkau B, Heude B, Charpentier G, Hudson TJ, Montpetit A, Pshezhetsky AV, Prentki M, Posner BI, Balding DJ, Meyre D, Polychronakos C, Froguel P: A genome-wide association study identifies novel risk loci for type 2 diabetes. Nature 2007, 445:88I-885.

19. Zeggini E, Weedon MN, Lindgren CM, Frayling TM, Elliott KS, Lango $H$, Timpson NJ, Perry JR, Rayner NW, Freathy RM, Barrett JC, Shields B, Morris AP, Ellard S, Groves C], Harries LW, Marchini JL, Owen KR, Knight B, Cardon LR, Walker M, Hitman GA, Morris AD, Doney AS, Wellcome Trust Case Control Consortium (WTCCC), McCarthy MI, Hattersley AT: Replication of genome-wide association signals in UK samples reveals risk loci for type 2 diabetes. Science 2007, 316:|336-|34|.

20. Scott LJ, Mohlke KL, Bonnycastle LL, Willer CJ, Li Y, Duren WL, Erdos MR, Stringham HM, Chines PS, Jackson AU, Prokunina-Olsson L, Ding CJ, Swift AJ, Narisu N, Hu T, Pruim R, Xiao R, Li XY, Conneely KN, Riebow NL, Sprau AG, Tong M, White PP, Hetrick KN, Barnhart MW, Bark CW, Goldstein JL, Watkins L, Xiang F, Saramies J, Buchanan TA, Watanabe RM, Valle TT, Kinnunen L, Abecasis GR, Pugh EW, 
Doheny KF, Bergman RN, Tuomilehto J, Collins FS, Boehnke M: A genome-wide association study of type 2 diabetes in Finns detects multiple susceptibility variants. Science 2007, 3 16: |34|-1345.

2I. Steinthorsdottir V, Thorleifsson G, Reynisdottir I, Benediktsson R, Jonsdottir T, Walters GB, Styrkarsdottir U, Gretarsdottir S, Emilsson V, Ghosh S, Baker A, Snorradottir S, Bjarnason H, Ng MC, Hansen T, Bagger Y, Wilensky RL, Reilly MP, Adeyemo A, Chen Y, Zhou J, Gudnason V, Chen G, Huang H, Lashley K, Doumatey A, So WY, Ma RC, Andersen G, Borch-Johnsen K, Jorgensen T, van Vliet-Ostaptchouk JV, Hofker MH, Wijmenga C, Christiansen C, Rader DJ, Rotimi C Gurney M, Chan JC, Pedersen O, Sigurdsson G, Gulcher JR, Thorsteinsdottir $U$, Kong A, Stefansson K: A variant in CDKALI influences insulin response and risk of type 2 diabetes. Nature Genetics 2007, 39:770-775.

22. Wenzlau JM, Juhl K, Liping Y, Moua O, Sarkar SA, Gottlieb P, Rewers M, Eisenbarth GS, Jensen J, Davidson HW, Hutton JC: The cation efflux transporter ZnT8 (SIc30A8) is a major autoantigen in human type I diabetes. PNAS 2007, 104: 17040-17045.

23. Brorsson C, Bergholdt R, Sjögren M, Eising S, Sørensen KM, Hougaard DM, Orho-Melander M, Groop L, Pociot F: A non-synonymous variant in SLC30A8 is not associated with type I diabetes in the Danish population. Mol Genet Metab 2008, 94(3):386-8.

24. Qu HQ, Grant SF, Bradfield JP, Kim C, Frackelton E, Hakonarson H, Polychronakos C: Association analysis of type 2 diabetes Loci in type I diabetes. Diabetes 2008, 57(7): 1983-6.

25. Sparre T, Larsen MR, Heding PE, Karlsen AE, Jensen ON, Pociot F: Unraveling the pathogenesis of type I diabetes with proteomics: present and future directions. Molecular and Cellular Proteomics 2005, 4:44I-457.

26. Nielsen K, Kruhøffer M, Ørntoft T, Sparre T, Wang H, Wollheim C, Jørgensen MC, Nerup J, Karlsen AE: Gene expression profiles during $\beta$ cell maturation and after IL-I $\beta$ exposure reveal important roles of $\mathrm{Pdx}-\mathrm{I}$ and $\mathrm{Nkx6}$.I for IL-I $\beta$ sensitivity. Diabetologia 2004, 48:2185-2199.

27. Kutlu B, Cardozo AK, Darville MI, Kruhøffer M, Magnusson N, Ørntoft $T$, Eizirik DL: Discovery of gene networks regulating cytokine-induced dysfunction and apoptosis in insulin-producing INS-I cells. Diabetes 2003, 52:2701-27I9.

28. Delaney CA, Pavlovic D, Hoorens A, Pipeleers DG, Eizirik DL: Cytokines induce deoxyribonucleic acid strand breaks and apoptosis in human pancreatic islet cells. Endocrinology 1997 |38:26|0-26|4.

29. Sandler S, Bendtzen K, Borg LA, Eizirik DL, Strandell E, Welsh N: Studies on the mechanisms causing inhibition of insulin secretion in rat pancreatic islets exposed to human interleukin-I $\beta$ indicate a perturbation in the mitochondrial function. Endocrinology 1989, I24:|1492-I50|.

30. Welsh N, Margulis B, Borg LA, Wiklund HJ, Saldeen J, Flodström M, Mello MA, Andersson A, Pipeleers DG, Hellerström C, et al:: Differences in the expression of heat-shock proteins and antioxidant enzymes between human and rodent pancreatic islets: implications for the pathogenesis of insulin-dependent diabetes mellitus. Molecular Medicine 1995, I:806-820.

31. Ohara-Imaizumi M, Cardozo AK, Kikuta T, Eizirik DL, Nagamatsu S: The cytokine interleukin-Ibeta reduces the docking and fusion of insulin granules in pancreatic beta-cells, preferentially decreasing the first phase of exocytosis. Journal of Biological Chemistry 2004, 279:4I 27I-4I274.

32. Cavallo MG, Monetini L, Valente L, Barone F, Beales P, Russo M, Pozzilli P: Glutathione protects a human insulinoma cell line from tumor necrosis factor-alpha-mediated cytotoxicity. International Journal of Clinical and Laboratory Research 1997, 27:44-47.

33. Lortz S, Tiedge M, Nachtwey T, Karlsen AE, Nerup J, Lenzen S: Protection of insulin-producing RINm5F cells against cytokinemediated toxicity through overexpression of antioxidant enzymes. Diabetes 2000, 49: I |23-II30.

34. Chen H, Carlson EC, Pellet L, Moritz JT, Epstein PN: Overexpression of metallothionein in pancreatic $\beta$-cells reduces streptozotocin-induced DNA damage and diabetes. Diabetes 200I, 50:2040-2046.

35. Casteele M Van de, Kefas BA, Ling Z, Heimberg H, Pipeleers DG: Specific expression of Bax-omega in pancreatic $\beta$-cells is down regulated by cytokines before the onset of apoptosis. Endocrinology 2002, 143:320-326.
36. Oltvai ZN, Milliman CL, Korsmeyer SJ: Bcl-2 heterodimerizes in vivo with a conserved homolog, Bax, that accelerates programmed cell death. Cell 1993, 27:609-619.

37. Andersen HU, Mauricio D, Karlsen AE Mandrup-Poulsen T, Nielsen $\mathrm{JH}$, Nerup J: Interleukin-I beta-induced nitric oxide production from isolated rat islets is modulated by D-glucose and 3 isobutyl-I-methyl xanthine. Eur J Endocrinol 1996, I34(2):25I-9.

38. Livak KJ, Schmittgen TD: Analysis of relative gene expression data using real-time quantitative PCR and the 2(-Delta Delta C(T))Method. Methods 200I, 25(4):402-8.

39. Zalewski PD, Millard SH, Forbes IJ, Kapaniris O, Slavotinek A, Betts $\mathrm{WH}$, Ward AD, Lincoln SF, Mahadevan I: Video image analysis of labile zinc in viable pancreatic islet cells using a specific fluorescent probe for zinc. J Histochem Cytochem 1994, 42:877-884.

40. Garg VK, Gupta R, Goyal RK: Hypozincemia in diabetes mellitus. Journal of Association of Physicians of India 1994, 42:720-72I.

4I. Roussel AM, Kerkeni A, Zouari N, Mahjoub S, Matheau JM, Anderson RA: Antioxidant effects of zinc supplementation in Tunisians with type 2 diabetes mellitus. Journal of the American College of Nutrition 2003, 22:316-32I.

42. Ho E, Quan N, Tsai YH, Lai W, Bray TM: Dietary zinc supplementation inhibits NFkappaB activation and protects against chemically induced diabetes in CDI mice. Exp Biol Med (Maywood) 200I, 226: I03-III

43. Getz G, Levine E, Domany E: Coupled two-way clustering analysis of gene microarray data. Proc Natl Acad Sci U S A 2000, 97: 12079-84.

44. Chandra J, Yang SN, Köhler M, Zaitsev S, Juntti-Berggren L, Berggren PO, Zhivotovsky B, Orrenius S: Effects of serum from patients with type I diabetes on primary cerebellar granule cells. Diabetes 200I, 50:77-8I.

45. Chimieniti F, Seve M, Richard S, Mathieu J, Favier A: Role of cellular zinc in programmed cell death: temporal relationship between zinc depletion, activation of caspases, and cleavage of Sp family transcription factors. Biochemical Pharmacology 2001, 62:51-62

46. Baynes JW: Role of oxidative stress in development of complications in diabetes. Diabetes $1991,40: 405-412$.

47. Priel $\mathrm{T}$, Hershfinkel M: Zinc influx and physiological consequences in the beta-insulinoma cell line, Min6. Biochem Biophys Res Commun 2006, 346:205-12.

48. Palmer JP, Helqvist S, Spinas GA, Mølvig J, Mandrup-Poulsen T, Andersen HU, Nerup J: Interaction of beta-cell activity and ILI concentration and exposure time in isolated rat islets of Langerhans. Diabetes 1989, 38(10):1211-6.

49. Eizirik DL, Mandrup-Poulsen T: A choice of death - the signaltransduction of immune-mediated $\beta$-cell apoptosis. Diabetologia 200I, 44:2II5-2I33.

50. Mandrup-Poulsen T: Apoptotic signal transduction pathways in diabetes. Biochem Pharmacol 2003, 66(8): I433-40.

5I. Ortis F, Pirot P, Naamane N, Kreins AY, Rasschaert J, Moore F, Théâtre E, Verhaeghe C, Magnusson NE, Chariot A, Orntoft TF, Eizirik DL: Induction of nuclear factor-kappaB and its downstream genes by TNF-alpha and IL-I beta has a pro-apoptotic role in pancreatic beta cells. Diabetologia 2008, 5 I(7): 12 |3-25.

\section{Pre-publication history}

The pre-publication history for this paper can be accessed here:

http://www.biomedcentral.com/1472-6823/9/7/prepub 